\title{
THE IMPLEMENTATION OF EICC CODE OF CONDUCT IN THE ELECTRONICS INDUSTRY SUPPLY CHAIN IN MALAYSIA
}

\author{
Ong Choon Hee \\ College of Business, Universiti Utara Malaysia, Sintok, Kedah, Malaysia
}

\begin{abstract}
This paper studied the EICC Code of Conduct implementation and listed the challenges that the participants experienced in Malaysia. Despite the benefits that EICC Code offers, participants should take anticipative approach to face the challenges to ensure the Code is successfully implemented. The intention of this paper is to highlight the challenges and provide recommendations to guide the participants in the electronics industry supply chain in complying with the EICC Code of Conduct.
\end{abstract}

\section{KEYWORDS}

Electronic Industry Citizenship Coalition (EICC) Code of Conduct, electronics industry supply chain, social responsibilities.

\section{INTRODUCTION}

For several decades, manufacturing companies in the electronics industry supply chain have always focused on productivity and quality in meeting customer demands in the highly competitive market. Profit and loss seem to be the crucial measurement to determine a company existence in today's world. To certain extent, manufacturing companies are willing to forgo the workers' rights and welfare in order to achieve production targets. Long working hours is one of the ways used by organizations to achieve production output. Substantial overtime may seem lucrative to the workers but it may not produce quality products in return. Instead, long working hours will result less concentration and produce more rejects. Furthermore, inadequate rest can cause fatigue that increases the probability of accident occurrence. Nowadays, customers at the global level have realized this scenario and started to emphasize on human rights and welfare of the workers. Hence, it is time for the participants in the electronics industry supply chain to focus on their social responsibilities. They ought to give full attention on the workers' benefits in the organization. Few years ago, the Electronic Industry Citizenship Coalition (EICC) which mostly consists of Multi-National Corporations (MNCs) has established a Code of Conduct and requires its supply chain members to comply with the requirements. The EICC uses labour, ethics, health and safety, environmental and management system as principles in the process of drafting the Code. The EICC promotes social responsibilities in the electronics industry. Participants in the electronics industry supply chain are required to show their dedication in implementing the Code. If the participants are unable to comply with the requirements, they may be at risk of having their sales contract to be re-evaluated by their customers. In worst scenario, their sales contract may be terminated by the customers. Hence, all members in the electronics industry supply chain are urged to seriously comply with the Code and participate in the Validated Audit Process (VAP) as required by their customers. The Validated Audit Process is an industry solution for improving business practices in the electronics industry supply chain. 
International Journal of Managing Value and Supply Chains (IJMVSC) Vol.5, No. 2, June 2014

\section{EICC CODE OF CONDUCT}

In the wake of unlawful discrimination and inhumane treatment towards migrant workers, the Electronic Industry Citizenship Coalition (EICC) has established Code of Conduct to uphold human rights of the workers. The EICC Code also requires the participants to provide a safe workplace and carry out their business operation in an ethical and environmentally responsible manner. The intention of the EICC Code is to provide a foundation for the improvement of social and environmental conditions in the global electronics industry supply chain. The Code comprises 5 major components: Labour, health and safety, environmental, ethics and management system. Below are brief explanations of the 5 components based on the recent version of EICC Code of Conduct, 2012 [1].

\subsection{Labour}

The labour standard was drafted to ensure workers are treated with dignity and respect as understood by the international community [2]. It explains the importance of freely chosen employment where forced and bonded employments are not allowed in an organization. Workers are voluntarily offering themselves to work in the organization and they have the right to terminate their employment at any time they wish. Retention of the worker's personal documents is strictly prohibited. This is to prevent employers from using the documents as a condition for continued employment. Fees charged to the workers for employment must be reasonable and in accordance with the authority guidelines. Employers should not impose additional fee or collect extra deposit from the workers. Any worker under the age of 15 shall not be employed and those under the age of 18 should only carry out light duties in the organization. According to the Code, long working hours is not permitted because it will cause work strain. Hence, workers are not allowed to work more than 60 hours per week and they are entitled one day off in a week. Wages paid to the workers should follow the minimum amount set by the Government. Employers are not permitted to deduct wages from the workers as a disciplinary measure in the organization. To ensure fair treatment among the workers, a workforce free of inhumane treatment and discrimination is required under this standard. Workers should be treated fairly regardless of their gender, race and religion. They are protected from harassment and punishment at the workplace.

\subsection{Health and Safety}

The health and safety standard is to protect workers from work-related injury and illness. According to this standard, occupational hazards should be minimized through engineering and administrative controls. Wherever risks and hazards that cannot be adequately controlled by these means, personal protective equipment should be provided and ensure they wear it at all times at the workplace [3]. Safe work procedures are required to establish for every work station. Worker's understanding on the safe work procedures is important so that they can follow the procedures correctly. Potential emergency situations such as fire, explosion and chemical spillage shall be identified and equipped with detection devices and fire suppression equipment. Work activities related to chemical usage are required to monitor periodically to ensure the exposure level is below the allowable limit. Physically demanding tasks such as repetitive lifting should be limited to certain weight which will not harm the workers. Those involve in prolonged standing and forceful assembly activities should rest intermittently to reduce the risk of body ache. Moving parts of the machines should be safeguarded with interlocks and barriers to prevent workplace injury. In terms of sanitation, food and housing, adequate facilities and amenities shall be provided in the workers' dormitories to fulfil living needs. The dormitories shall be maintained clean and safe at all times with reasonable personal space and good ventilation. 
International Journal of Managing Value and Supply Chains (IJMVSC) Vol.5, No. 2, June 2014

\subsection{Environmental}

Environmental responsibilities are important for the participants in the electronics industry supply chain. The participants shall safeguard the environment from any adverse effects caused by the factory operation. Environmental permits shall be obtained prior to operating the factory. All discharge and emission from the premise must be monitored and complied with the regulatory requirements [4]. Pollution prevention shall be the first environmental objective of the organization. Water and energy usage should be minimized as far as practicable with the available technology. According to the regulations, all wastes shall be disposed through licensed contractors and their disposals must be recorded. Apart from that, participants should adhere to the product content restriction guidelines to ensure hazardous substances do not exist in the product composition. If hazardous substance is detected in the product, it should be replaced with those non-hazardous ones. Periodical test reports are required to submit to customers as proof of compliance with the guidelines.

\subsection{Ethics}

Excellent business ethics will enable an organization to meet social responsibilities and to succeed in the marketplace. Ethics in the EICC Code cover a wide range of practices. One of the practices is referred as business integrity where any forms of bribery, corruption, extortion and embezzlement are prohibited. Fair trade is also to be upheld in a competitive manner. The organization shall refrain from carrying out anti-competitive agreements with competitors to fix price, make rigged bids or form trade cartel. Marketing activities shall be carried out according to the actual situations of the organization. Accurate and correct business information should be shared and made available to the relevant parties. As stated in the Code, organizations shall adhere to the conflict mineral requirements and exercise due diligence on the source and chain of custody of the minerals. The mineral sourcing information shall be informed to customers upon request. Under the ethics code, confidentiality of employee's personal information and supplier's identity is protected. In addition, protection of whistle-blowers is practiced so that the related personnel shall not fear of raising any concerns and wrongdoings in the organization. At the same time, the organization shall not retaliate against any employee for exercising any right granted for testifying, assisting or participating in an investigation related to the organization. Disclosure of business information should be in accordance with the applicable regulations and intellectual property rights are to be respected in all business dealings [1].

\subsection{Management System}

In order to implement the EICC Code effectively, participants shall adopt a management system to facilitate the requirements in the Code [1]. A steering committee consists of senior management shall lead the organization in complying with the standard. Elements in the management system shall include company commitment, management responsibility, supplier responsibility and other activities based on the plan-do-check-action (PDCA) principle. Improvement objectives should be set at relevant functions in the organization in line with the EICC policy. Generally, targets and implementation plans are established to achieve the set objectives. Trainings and briefings will be conducted to disseminate the information to the workers. To ensure the system is working effectively, periodic audit and assessment will be conducted to rate the level of conformity to the EICC Code. Timely corrective actions should be taken against any non-conformity to prevent recurrence. The organization shall also conduct management review at least once in a year to ensure adequacy of the EICC management system. Worker's feedback is important to obtain information on their understandings of the EICC Code. The Code shall be communicated to the suppliers as well to facilitate continuous improvement in the entire electronics industry supply chain. 
International Journal of Managing Value and Supply Chains (IJMVSC) Vol.5, No. 2, June 2014

\section{BENEFITS OF THE EICC CODE OF CONDUCT}

Referring to the components of EICC Code of Conduct, it covers various aspects such as human rights, health and safety, business ethics, environmental and management system. It is not only directing the participants to do the right things but also bring business benefits to the entire electronics industry supply chain. Being a responsible participant who demonstrates social responsibilities, it is expected to gain more trust from the customers in business dealings. Indeed, customers prefer to deal with responsible suppliers and always emphasize on their social activities. Some of the customers insist that suppliers must comply with social accountability standard while others look at their contribution to the community. The EICC Code is a standard that sets the participants apart from being an ordinary citizen. It is about behaving in a responsible way and contributes towards the wellbeing of the society. Those participants complied with EICC Code will have better hiring capability. Generally, employees prefer to work longer in an organization that cares for their welfare. In terms of environmental benefits, the Code also assists the participants in complying with environmental regulations. It guides organizations in protecting the environment and preserving the natural resources. By performing activities such as reducing, reusing and recycling wastes, organizations are able to reduce their operation costs. As for health and safety, a safe and healthy work environment will minimize lost time injury and illness that makes the workers more productive. Other EICC activities such as performing fair trade will bring positive impact to the organization. In summary, EICC Code not only improves the working conditions of the electronics industry but also foster the relationship between the participant and the local community. However, along the journey of implementation, there are challenges that the participants have to aware to ensure a smooth and successful implementation.

\section{The Challenges 4.1 Budget Constraint}

Budget constraint is a common problem faced by most of the organizations during the implementation of EICC Code. In view of the dormitory requirements, the organization has to allocate a budget for upgrading hostel facilities and providing amenities as required by the Code. The additional amenities will definitely increase the dormitory maintenance cost. Owing to the allowable working hours should not exceed 60 hours per week; additional workforce maybe required if the organization would like to maintain the current operating capacity. Therefore, it requires extra cost to employ additional workers. Further, the Malaysian government has just launched the minimum wages recently which is higher than the previous wages. In this case, organizations have to bear additional cost of wages, dormitory and transport simultaneously. It would certainly add to the current expenses of the organization.

\subsection{Working Hours}

The working hour of 60 hours per week is a tough challenge for all the organizations regardless of their size. The EICC working hours is stricter than the Government guidelines where organizations have to re-arrange their work shift pattern to comply with the requirement. Additional headcount is needed if the organization would to maintain the production capacity with 60 work hours per week. With the 60-hour schedule, overtime will be reduced and it will affect the worker's take home pay. Subsequently, it may also impact the organization recruitment capability. It is suggested that the 60 work hours should be reviewed by taking into consideration the work culture in developing countries like Malaysia. Appropriate measures shall be in place to resolve this issue; otherwise it may weaken the entire electronics industry supply chain in the long run. 


\subsection{Cost Impact}

The additional manpower cost will impose the biggest impact to the production cost. In order to maintain the operation cost, cost cutting measures maybe be used to control purchases and expenses. When the organization is facing financial strain, activities such as downsizing and retrenchment may take place to further reduce the operation cost. If the cost impact is not handle well by the organizations, it can cause the entire supply chain losing its strength and putting the electronics industry at risk.

\subsection{Management Commitment}

Management commitment indicates the extent to which top management demonstrates supportive and positive attitudes towards the implementation of EICC Code. Serious management commitment is required to develop a climate that promotes the implementation of EICC Code in the organization. In this case, management may face a tough situation in view of the increasing operation cost. Fulfilling customer requirements seems important to the participants, but ensuring the organization stays healthy financially is crucial. Hence, management has to establish contingency plans to overcome unforeseen circumstances that may affect the organization financial strength.

\section{RECOMMENDATIONS}

The biggest challenge that the organizations faced during the implementation of EICC Code is the cost impact. Recommendations are provided in this paper specifically to guide the organizations to overcome the challenges. In order to reduce the operating cost, it is suggested that organizations seek for price increase from their customer to ease their financial strain. As the working hour is the main factor of causing the cost impact, human resource department plays an important role to propose work schedule that complies with the 60-hour work week. The work schedules may include change of work shift pattern such as 1 shift 2 groups to minimize production idling time. Another way of overcoming the work hour issue is to seek for reliever from 60 to 63 work hours per week. A 63-hour work shift pattern will enable the workers to work for 6 days with one day rest (see Table 1). The 63-hour shift pattern will be advantageous for both suppliers and customers as it allows 2 shifts with minimum adjustment of work schedule. The other alternative of reducing working hours is to increase automation in the organization. Generally, automation reduces manual handling and thus requires less manpower to operate the machines. This in turn will reduce production cycle time and increase productivity. In the long run, automation may be the best solution for manpower shortage. At the same time, employing fewer workers will also reduce the cost of accommodation and transport.

Table 1: Proposed 63-hour 2-Shift Pattern

\begin{tabular}{|c|c|c|c|c|c|c|}
\hline & $\begin{array}{c}\text { Regular } \\
\text { (hours) } \\
\text { A }\end{array}$ & $\begin{array}{c}\text { Overtime } \\
\text { (hours) } \\
\text { B }\end{array}$ & $\begin{array}{c}\text { Break Time } \\
\text { (hours) } \\
\text { C }\end{array}$ & $\begin{array}{c}\text { Work } \\
\text { hours per } \\
\text { day } \\
\text { A+B-C }\end{array}$ & $\begin{array}{c}\text { Day 1 - Day 6 } \\
\text { (Total hours) } \\
\mathbf{1 0 . 5} \text { x 6 }\end{array}$ & Day 7 \\
\hline Shift 1 & 8 & 4 & 1.5 & 10.5 & 63 & Off \\
\hline Shift 2 & 8 & 4 & 1.5 & 10.5 & 63 & Off \\
\hline
\end{tabular}


International Journal of Managing Value and Supply Chains (IJMVSC) Vol.5, No. 2, June 2014

\section{ConClusion}

This paper has listed the benefits and challenges of the EICC Code of Conduct. The purpose of the EICC Code no doubt is to advance the participants' social responsibilities in the electronics industry supply chain. However, it is important that the Code shall not affect the operation of the company so that it can form mutually beneficial relationships between the customers and suppliers. Hence, it is the intention of this paper to provide recommendations to the participants to create values with their customers and suppliers in line with EICC Code implementation.

\section{REFERENCES}

[1] Electronic Industry Citizenship Coalition Code of Conduct (2012), Version 4, March 2012, www.eicc.info.

[2] International Standard: SA 8000:2008 Social Accountability (2008), Social Accountability International.

[3] OHSAS 18001:2007 Occupational Health and Safety Management Systems - Requirements (2007), First Edition, July 2007.

[4] International Standard: ISO 14001 Environmental Management Systems - Requirements with guidance for use (2004), Second Edition, 15 November, 2004.

\section{Author}

Ong Choon Hee is a DBA graduate from Universiti Utara Malaysia. His publications have appeared in journals such as the International Journal of Trade, Economics and Finance, International Journal of Arts and Commerce, IOSR Journal of Business and Management, The International Journal's Research Journal of Social Science and Management, International Journal of Academic Research in Business and Social Science and etc. 